\title{
The Construction of Customary Village Rules Tests After The Enactment of Law Number 6 of 2014 on Villages (A Study on Awig-awig of Customary Village/Pakraman Village in Bali Province Indonesia)
}

\author{
Putera Astomo $^{1}$, Retno Saraswati ${ }^{2}$ Sukirno $^{3}$ \\ \{putraastomo_hukum@yahoo.co.id ${ }^{1}$, saraswatiretno@yahoo.co.id ${ }^{2}$, kirnoundip@yahoo.com ${ }^{3}$ \}
}

${ }^{1}$ West Sulawesi University, Majene, Indonesia

${ }^{2,3}$ Diponegoro University, Semarang, Indonesia

\begin{abstract}
The formation of Law Number 6 of 2014 on Villages and its implementing regulations govern the mechanism of testing of Village Rules including the testing of Awig-awig as a Customary Village Rules applicable in Customary Village/Pakraman Village of Bali Province. However, the mechanism of testing of Village Rules governed in the Act poses various problems when applied to test the Awig-awig of Customary Village/Pakraman Village in Bali Province as follows: First,the type of village is divided by two, namely the Official Administrative Village and Customary Village/Pakraman Village, where both types of village have different characteristics. Secondly, the application of the Law as positive law is contrary to the customary law that applies in Customary Village/Pakraman Village because people still maintain the customary law, which is derived from the values of the teachings of Hinduism and traditions that live in the community. Third, the Official Administrative Village has a hierarchical relationship with the Government, Local Government, and Sub-district, while Customary Village/Pakraman Village is autonomous so that Customary Village/Pakraman Village can create and establish Awig-awig as a regulation in order to organize and manage community life in religion, social, and cultural sectors. Fourth, it should be understood that Law Number 6 of 2014 on Villages and its implementing regulations govern the mechanism of testing of Village Rules in the form of evaluation of Village Rules Design and clarification of Village Rules which has been approved by the Village Head together with the Village Representative Body. While in Bali Province, Awig-awig which is in the form of a draft is not tested through evaluation by the Regent/Mayor. Similarly, Awigawig that has been established and endorsed by Krama of Customary Village/Pakraman Village is not tested through clarification by Regent/Mayor,even if it is directly applied in Customary Village/Pakraman Village so that Law Number 6 of 2014 on Villages and its implementing regulations shall not be applicable to the test of Awig-awig. The problem formulated is: What are the consequences caused when Law Number 6 of 2014 on Villages and its implementing regulations applied in testing Awig-awig of Customary Village/Pakraman Village in Bali Province? The approach methods of this research are sociology law and anthropology law. The result of the research shows that Awig-awig of Customary Village/Pakraman Village cannot be tested because it causes terrible consequences for the life of Customary Village/Pakraman Village both philosophically, juridical, socially, and culturally.
\end{abstract}

Keyword: Testing Construction, Village Customary Rules, Law Number 6 of 2014 on Villages, Awig-awig of Customary Village/Pakraman Village in Bali Province. 


\section{Introduction}

The existence of The Village as a unit of customary law community is affirmed in Article 18B Paragraph (2) of the 1945 Constitution of the Republic of Indonesia which states that the State recognizes and respects the unity of indigenous and tribal peoples as long as they are alive and in accordance with the development of society and the principle of the Unitary State of the Republic Indonesia, as governed by law. Also, it is affirmed in Article 28I Paragraph (3) of the 1945 Constitution of the Republic of Indonesia which states that the cultural identity and the rights of traditional communities are respected in harmony with the development of the times and civilizations.

Article 18B Paragraph (2) of the 1945 Constitution of the Republic of Indonesia mandates that The Unit of Customary Law Community shall be further regulated in the Act so that a new laws construct which regulates the Village shall be established. The Law Number 6 of 2014 years about The Village in which the Act asserts that The Law Number 32 of 2004 years which regulates the village has been declared no longer valid.

Definition of village is mentioned in article 1 paragraph (1) of Law Number 6 of 2014 on Villages, which states that as village or customary village or called by another name, hereinafter referred to as Village, is a unit of law society which has territory boundaries to be arranged and administers Government affairs, public interest based on community initiative, right of origin, and/or traditional rights recognized and respected within the system of government of the Unitary State of the Republic Indonesia.

In the Republic of Indonesia, the construction of a new law governing the Villages is Law Number 6 of 2014 on Villages in which this Law divides the village into Village and Customary Village where Village and Customary Village basically perform almost similar tasks, whereas the difference is only in the implementation of the right of origin, especially concerning the social preservation of Customary Village, the arrangement and management of custom territory, customary peace, maintaining tranquility and order for customary law community, and governance arrangements based on the original arrangement.

The authority of attribution and delegation becomes the basis for the Customary Village Government to establish the Customary Village Rule's aimed at regulating the governance and community life based on the original composition and the right of the origin and traditional rights within the framework of the Unitary State of the Republic of Indonesia.

One example of Customary villages studied is Customary Village/Pakraman Villagein Bali Province of Indonesia whose existence is based on the Provincial Regulation of Bali's First Level Regional Number 6 of 1986 on Position, Function, and Role of Customary Villages as a Unity of Customary Law Community in Bali Province which then amended by Regional Regulation of Bali Province Number 3 of 2001 on Pakraman Village.

One of the essential things in Customary Village/Pakraman Villageis the existence and position of "Awig-awig."

The definition of Awig-awig is mentioned in Article 1 part (11) Regional Regulation of Bali Province Number 3 of 2001 on Pakraman Village which states that Awig-awig is a rule made by Krama Pakraman Village and or Krama Banjar Pakraman that is used as a guide in the implementation of Tri Hita Karana according to Mawacara village and religious dharma in Pakraman Village or Banjar Pakraman respectively.

When Awig-awig is associated with the testing of Village Rules, the testing mechanism is regulated in Law Number 6 of 2014 and its implementing regulations. The implementing regulations are Government Regulation Number 43 of 2014 on the Implementation of Law 
Number 6 of 2014 on Villages and the Minister of Home Affairs Regulation Number 111 of 2014 on the Technical Guidelines of Village Rules.

However, Law Number 6 of 2014 on Villages and its implementing regulations, which govern the mechanism of testing of Village Rules including the Customary Village Rules, pose problems when applied to test Awig-awig as a rule for Customary Village/Pakraman Village in Bali Province. First, the type of village is divided by two, namely the Official Administrative Village and Customary Village/Pakraman Village,where both types of the village have different characteristics.

Secondly, the application of the Law as positive law is contrary to the customary law that applies in Customary Village/Pakraman Village, because people still maintain the customary law which is derived from the values of the teachings of Hinduism and traditions that live in the community.

Third, the Official Administrative Village has a hierarchical relationship with the Government, Local Government, and Sub-district, while Customary Village/Pakraman Village is autonomous so that Customary Village/Pakraman Village can create and establish Awig-awig as a regulation in order to organize and manage community life in religion, social, and cultural sectors.

Fourth, it should be understood that Law Number 6 of 2014 on Villages and its implementing regulations govern the mechanism of testing of Village Rules in the form of evaluation of Village Rules Design and clarification of Village Rules which has been approved by the Village Head together with the Village Representative Body. While in Bali Province, Awig-awig, which is in the form of a draft, is not tested through evaluation by the Regent/Mayor. Similarly, Awig-awig that has been established and endorsed by Krama of Customary Village/Pakraman Village is not tested through clarification by Regent/Mayor,even though it is directly applied in Customary Village/Pakraman Village so that Law Number 6 of 2014 on Villages and its implementing regulations shall not be applicable to the test of Awig-awig.

Based on the background described, then the problem formulated is: What are the consequences caused when Law Number 6 of 2014 on Villages and its implementing regulations applied in the testing Awig-awig of Customary Village/Pakraman Village in Bali Province?

\section{Methodology}

The methods of approach used in this study include: (1) sociology law, in which Awigawig is a regulation created and established and adhered together by Krama ofCustomary Village/Pakraman Villagein order to realize the life of the community in Customary Village/Pakraman Village of Bali Province that is safe, orderly, peaceful, and prosperous. (2) anthropology law, in whichthat Awig-awig is not only a regulation that binds the Customary Village/Pakraman Village in Bali Province but also as a cultural symbol which aims to preserve the values of customs that originate from the teachings of Hinduism and traditions that live in society.

\section{Findings}

According to Sardjono Jatiman, the village is a legal unity. The system of government is a social system that grows and develops along with the growth of society. The statement 
"village is a social system with its institution" means that the village has political, economic, judicial, and socio-cultural institutions developed by its community. For example, in a political institution, a village has a village head and a village apparatus where the procedures and arrangements of the main tasks and functions are developed on their initiative rather than on the instructions of the government above them. The village economic institutions have a communal land system/layout whose arrangements are selfdeveloped. In the field of village justice, it has its village court to resolve conflicts between citizens or impose criminal sanctions for violations of customary law; and in the sociocultural field, the village has a unique working together system of its invention and development. The persistent and stable institutional community of the villagers eventually became customs. Therefore, the experts mentioned that the village had become a unitary customary community law because the institution made is running continuously, which eventually become customs for the villagers concerned[1].

The same thing was also expressed by Van Vollenhoven, that the village is a unitary customary law community. The study of the law community focused on communal societies, people who have characteristics of unity and harmony and are bound by the same cultural values system, know each other, have a relatively close relationship and have worked together spirit. The customary law community is derived from the existence of the communal society, which develops institutions that are used to meet the needs of both physical and spiritual life. In subsequent developments, the formed institutions become the basis of the system implementation of society. With the existence of a social system established based on self-developed institutions and maintained as the basis of the system of life, the customary law community was formed [2].

In contrast to the opinion that village is a unitary customary law community, Terhaar argues that customary law community is the unity of man as a whole, to settle in a particular area, to have rulers, to have tangible or intangible property, in which members of the unity of each experience life in society, is a natural and none of them has any thought or tendency to wish to dissolve the growing bond or to abandon it in the sense of breaking away from that bond forever [3].

According to Safrudin Bahar, indigenous and tribal people are a homogeneous anthropological community and are continuously inhabiting a particular territory, having historical and mystical connections to their past history, feeling themselves and being viewed by outsiders as coming from a common ancestor, and having a distinctive identity and culture that they wish to preserve for the next historic period, and having no dominant position in existing political structures and systems [4].

According to Hazairin, the customary law communities, such as villages in Java, clans in South Sumatra, Nagari in Minangkabau, Kuria in Tapanuli, wanua in South Sulawesi, our community units that have the equipment to stand alone. They have a unity of law, rule, and environmental unity based on the universal right of land and water for all its members. The form of family law (patrilineal, matrilineal, or parental) affects the system of governance primarily based on agriculture, livestock, fishery and harvesting of forest products and water products, plus by hunting wild animals, mining, and creating handicrafts. All members are equal in rights and obligations. Their livelihood is communal, where gotong royong, helping each other always have a significant role [5].

According to WidyaSatya Dharma, customary village is a unity of society where certain areas bind the sense of unity as indigenous villagers (village reefs) with clear boundaries and also bound by a system of praying places called the Kahyangan Tiga (Three Temples) of Pura Desa, Pura Puseh, and Pura Dalem [6]. 
According to I Gusti Raka Gede, thatcustomary village is a unity of territory in which its citizens jointly conceptualize and activate religious ceremonies to preserve the sanctity of the village. The sense of unity as the indigenous villagers is bound by the existence of the village's reefs (village area), the village Awig-awig (the village rule system with its implementing regulations), and the temple of three (three village temples, as a system of prayers for indigenous villagers)[7].

According to I Ketut Sukadana, the elements of customary village as customary law community are as follows: a) showing the form of a territorial unity with village boundaries as the realization of customary village areas, b) creating a unity of kinship in the form of karma desa and collected in some banjar as the smallest set of kinship that is inseparable from the activities of traditional village, c) is a unit of worship of the Kahyangan Tiga, d) is a form of unity of activities in the togetherness of the Ayahan Desa (duties and obligations as Kramaof Village) and e) has a governance structure [8].

According to the writer, that the definition of the village and customary village, Customary Village/Pakraman Villageis the United Society of Customary Law, and it is socially religious. One of the visible religious symbols is the society's belief toward Hindu that embeds religious contents to strengthen Tri Hita Karana, which is dealing with interconnection with each other, involving the relationship between God and human, the relationship between human, and the relationship between human and the Universe. The society belief is also implemented into Kahyangan Tiga (Three Temples), involving Pura Agung, Pura Dalem, and Pura Puseh, in which it becomes the location for conducting religious rituals in order to worship Shang Yang Widhi Wash (God the Almighty).

The concept of customary law can also be connected with Awig-awig. According to C. Snouck Hurgronje, customary law is a custom which has sanction (reaction), while a custom that does not have sanction (reaction) represents a normative practice. The practice resembles the behaviors in society. Either customary law or customary practice has an unobvious limit. According to Van Vollenhoven, customary law is the behavioral regulations applied to native people as well as foreign eastern people. They have sanctions (then considered as law), but they are not codified (then considered as custom). According to TerHaar, customary law is the full regulations created from the decisions made by the law functionaries (in a broad sense) who have authority and are influential, in which the society under regulations obeys wholeheartedly. The everlasting process of customary law is created and maintained by and within the decision of the authorities. According to Bellefroid, customary law is living regulations, which even though there is no law made by respected authorities, the society keeps following the regulations since they believe that it applies as the law itself [9].

According to Otje Salman, customary law has unique characteristics in comparison with the other law system. Its three unique characteristics are highly traditional, possible to be changed, and able to adjust [10]. These characteristics show that even though custom maintains traditional values, at the same time, customary law could accept substantial changes [11]

Based on the discussed definition of customary law, there is a significant correlation between religious society and applied customary law in the Customary Village/Pakraman Village of Bali Province due to the fact the customary law has still been hereditary maintained. In order to preserve the law, bounding regulations should be carried out in order to rule out the life of the community so-called Awig-awig, the Awig-awig itself relies on the customary law of the community in Customary Village/Pakraman Village. The existence of Awig-awig will play a significant role as guidelines for the society and most 
importantly, to give customary sanction in the form of Karmapala sanction to those who break the rules.

Law theories could also be connected with Awig-awig. According to Bagir Manan, legislation means [12]:

1. Every written decision declared by the authorities will contain behavioral regulations which are generally bounding.

2. The behavioral regulations which contain provision related to the rights, obligations, functions, status, or orders.

3. The regulation which has general and abstract characteristics of which it neither rules nor is addressed to an object/event/specific concrete symptoms.

According to Satjipto Rahardjo, the characteristics of legislation are [13]:

1. General and comprehensive, in contrast with exclusive and limited.

2. Universal, created to deal with the upcoming unclear events. Therefore, it cannot be created only to overcome specific events.

3. Usually, there is clausal in the statutory regulations allowing re-evaluation.

According to the writer, legislation is the national regulation which has the following characteristics:

1. Written.

2. It is created by authorities.

3. General and abstract, generally means that it applies to the entire citizen while abstract means that each legislation does not rule in detail about a law event. Therefore, technical legislation is needed.

Based on the definition of legislation, it can be concluded that the characteristics of Awig-awig are as follow:

1. Written in Sansekerta.

2. Created by the Krama of the Customary Village/Pakraman Village.

3. Containing the unity of customary sanctions according to the applied law in the Customary Village/Pakraman Villageand is not against the legislation as well as the sense of justice in the society.

There have been cases where there was a violation of Awig-awig of Indigenous Villages

in Bali Province which was then subjected to customary sanctions such as:

1. Destruction of customary sanction in the form of kasepekang for community residents violating Awig-awig Tukadmungga of Customary Village, Buleleng District, Buleleng Regency in Bali Province.

2. The imposition of Sanctions Against Awig-awig Violation of Indigenous Villages by Krama of Village in Mengwi of Customary Village, Mengwi District, Badung Regency in Bali Province.

3. Destruction of customary sanction KarangMemadu for polygamy action in Penglipuran of Customary Village, Bangli District, Bangli Regency in Bali Province.

The theory of hierarchical norms can also be connected with Awig-awig. In Hans Kelsen's theory about hierarchical norms, it is explained that Grundnorm is the highest normative law in the hierarchy that it shapes a law pyramid (Stufenbau). Therefore, lex superior derogate lex inferior is applied, which means that the lowest law norms cannot be against the highest law norms. If there is conflict, the lowest law norms can be tested through the Grundnorm (the highest law norms). Hans Nawiasky explains that the term Grundnorm, as proposed by Hans Kelsen, is the National Fundamental Norms (Staats fundamental norm). If it is correlated with the system of law in Indonesia, A Hamid S 
Attamimi argues that the hierarchical norms proposed by Hans Nawiasky reflect as follows [14]:

1. Staatsfundamentalnorm is Pancasila.

2. Staatsgrundgesetz is the body of the 1945 Constitution of the Republic of Indonesia, TAP MPR, and constitutional convention.

3. Formellgesetz is the law.

4. Verordnung en autonomesatzung is by order, beginning from the government regulations until the decision of the governor.

In article 7 paragraph (2) Provincial Regulation of Bali's First Level Regional Number 6 of 1986 and article 11 paragraph (2) Provincial Regulation of Bali Province Number 3 2001 firmly state that Awig-awig in the Customary Village/Pakraman Village of Bali Province cannot be conflicted with the religion, Pancasila, the 1945 Constitution of the Republic of Indonesia, and the ongoing legislation.

According to Jimmy Asshiddiqie, law norms testing can be conducted through political review, administrative review, or judicial review [15].

The testing out of the Village Rules and the Customary VillageRules in Law Number 6 of 2014 on Villages and its implementing regulations. The regulation implements administrative review testing where the governor is given the authority to cancel the Village Rules or the Customary Village Rules, which are not by the legislation and public affairs.

Eventually, Awig-awig cannot be tested based on Law Number 6 of 2014 because canceling Awig-awig will ruin the life order of the Customary Village/Pakraman Villageof Bali Province, either its life of the religious society or the customary law applied inside. In testing the Awig-awig in Customary Village/Pakraman Village, Law Number 6 of 2014 about the Village and its implementing regulations might give negative impacts on the life of the society within the village either philosophically, juridically, socially, or culturally. The negative impacts are:

1. Philosophicalaspect, where the autonomy of Customary Village/Pakraman Villageis potentially disappearing due to national law intervention (legislation) which rules and also cancels Awig-awig as the customary law of Customary Village/Pakraman Village.

2. A juridical aspect that Awig-awig has a role in settling down custom and religious conflicts in the village. If Awig-awig is canceled by the national law (legislation), the social regulation of Customary Village/Pakraman Village will remain unclear since it is considered against the legislation. The cancellation of Awig-awig is conflicting with the customary law applied in the society of Customary Village/Pakraman Village, which is now still hereditary preserved.

3. The socialaspect, having its position as the United Society of customary law and socially religious, Awig-awig has a crucial social role in society. Awig-awig is made as a media to embody a unity between the Krama of the Customary Village/Pakraman Village in order that peace and serenity could be established within the society. If the legislation cancels Awig-awig, unity will be ruined, and a peaceful situation will not take place.

4. Cultural aspect, one of the development activities in the Customary Village/Pakraman Villageis by carrying out management towards national culture in a broad sense and Balinese culture in the narrow sense. In preserving the values of culture and customs, Awig-awig is not only a life regulation within society, but it is also a cultural symbol since it contains Sansekerta,which is based on philosophies as well as Hinduism religious values, including all the living traditions. Therefore, if Awig-awig is canceled, one cultural symbol will disappear. 


\section{Conclusion}

Based on the discussed descriptions, it can be concluded that there are negative impacts if Law Number 6 of 2014 about Village and its implementing regulations in examining the Awig-awig of Customary Village/Pakraman Village of Bali Province, involving: First, philosophicalaspect where the autonomy of Customary Village/Pakraman Village is potentially disappearing due to national law intervention (legislation) which rules and also cancels Awig-awig as the customary law of Customary Village/Pakraman Village. Second, the juridical aspect that Awig-awig has a role in settling down custom and religious conflicts in the village. If Awig-awig is canceled by the national law (legislation), the social regulation of Customary Village/Pakraman Villagewill remain unclear since it is considered against the legislation. The cancellation of Awig-awig is conflicting with the customary law applied in the society of Customary Village/Pakraman Village, which is now still hereditary preserved. Third,the social aspect, having its position as the United Society of customary law and socially religious, Awig-awig has an essential social role in society. Awig-awig is made as a media to embody a unity between the Krama of the Customary Village/Pakraman Village in order that peace and serenity could be established within the society. If the legislation cancels Awig-awig, unity will be ruined, and a peaceful situation will not take place. Fourth, cultural aspect, one of the development activities in the Customary Village/Pakraman Villageis by carrying out management towards national culture in a broad sense and Balinese culture in the narrow sense. In preserving the values of culture and customs, Awig-awig is not only a life regulation within society, but it is also a cultural symbol since it contains Sansekerta,which are based on philosophies as well as Hinduism religious values, including all the living traditions. Therefore, if Awig-awig is canceled, one cultural symbol will disappear.

\section{References}

[1] S. Jatiman, Dari Kampung Menjadi Desa Disertasi. Jakarta: Universitas Indonesia, 1995.

[2] H. Nurcholis, Pertumbuhan dan Penyelenggaraan Pemerintahan Desa. Jakarta: Erlangga, 2011.

[3] B. Muhammad, Asas-asas Hukum Adat Suatu Pengantar. Jakarta: Pradnya Paramita, 1986.

[4] S. Bahar, Kertas Posisi Hak Masyarakat Hukum Adat. Jakarta: Komisi Nasional Hak Asasi Manusia, 2006.

[5] S. Soekanto, Hukum Adat Indonesia. Jakarta: Raja Grafindo Persada, 2013.

[6] W. S. Dharma, "Jurnal Kajian Hindu Budaya dan Pembangunan," J. Kaji. Hindu Budaya dan Pembang., vol. 5, no. 2, p. 23, 1999.

[7] E. Y. N. S. Santosa, "Peran Desa Adat Dalam Pengembangan Pariwisata Di Bali," J. Apl. llmu-Ilmu Agama, vol. 4, no. 2, pp. 207-208, 2003.

[8] I. K. Sukadana, "Pola Hubungan Desa Adat dengan Desa," J. Kertha Wicaksana, vol. 10, p. $52,2000$.

[9] S. Tolib, Intisari Hukum Adat Indonesia Dalam Kajian Kepustakaan. Bandung: Alfabeta, 2013.

[10] R. Otje Salman, Rekonseptualisasi Hukum Adat Kontemporer. Bandung: Alumni, 2002.

[11] S. M. Salahuddin, "Peranan Hukum Adat dalam Pembangunan Hukum Nasional," J. Konstitusi, vol. 5, no. 2, p. 142, 2008.

[12] B. Manan, "Ketentuan-ketentuan Tentang Pembentukan Peraturan Perundang-undangan dalam Pembangunan Hukum Nasional Makalah pada pertemuan ilmiah tentang Kedudukan Biro-Biro Hukum/Unit KerjaDepartemen/LPND Dalam Pembangunan Hukum," Jakarta, 1994. 
[13] S. Rahardjo, Ilmu Hukum. Bandung: Alumni, 1996.

[14] A. H. S. Attamimi, "Peranan Keputusan Presiden Republik Indonesia dalam Penyelenggaraan Pemerintahan Negara: Suatu Studi Analisis Mengenai Keputusan Presiden yang Berfungsi Pengaturan Dalam Kurun Waktu PELITA I-PELITA IV Disertasi," Universitas Indonesia, 1990.

[15] J. Asshiddiqie, Model-Model Pengujian Konstitusional Di Berbagai Negara. Jakarta: Sinar Grafika, 2010. 